\title{
Metabolism Energy and Performance of Several Local Cattle Breeds Fed Rice Straw and Concentrate
}

\author{
Utami ETW, Bata M, Rahayu S \\ Faculty of Animal Science, Jenderal Soedirman University, Purwokerto 53122 \\ E-mail:muhamadbata@yahoo.com
}

(received 08-03-2021; revised 17-05-2021; accepted 24-05-2021)

\begin{abstract}
ABSTRAK
Utami ETW, Bata M, Rahayu S. 2021. Metabolisme energi dan performans beberapa bangsa sapi lokal yang diberi pakan jerami padi dan konsentrat. JITV 26(2): 57-64. DOI: http://dx.doi.org/10.14334/jitv.v26i2.2711.

Penelitian bertujuan mengkaji pengaruh bangsa sapi lokal terhadap metabolisme energi dan performans pada kondisi lingkungan dan pakan yang sama. Penelitian menggunakan empat bangsa sapi lokal yang berbeda 40 ekor sapi lokal jantan (2.5 tahun; BB awal 300.30 \pm 0.68 ) yang terdiri dari sapi Madura (M), sapi Sumba Ongole (SO), sapi Bali (B) dan sapi Bali Timor (BT) dan keempat jenis bangsa sapi tersebut sebagai perlakuan (10 ekor/perlakuan). Penelitian menggunaan rancangan acak kelompok (RAK) dengan bobot badan awal ternak sebagai kelompok. Jerami padi diberikan secara adlibitum dan pemberian konsentrat sebanyak $2.5 \%$ dari BB (BK 86.53\%). Peubah yang diukur yaitu konsumsi energi (KE), energi tercerna (ET), energi termetabolis (ME), retensi energi (RE), rasio RE terhadap KE, rasio RE terhadap ET, rasio C2/C3, efisiensi konversi heksosa menjadi VFA $(\mathrm{EKH})$ dan rataan pertambahan bobot badan harian $(\mathrm{PBBH})$. Hasil penelitian menunjukan bahwa perbedaan bangsa sapi lokal berpengaruh nyata $(\mathrm{P}<0.05)$ terhadap KE, ET, ME, RE, rasio RE terhadap KE, rasio RE terhadap ET, rasio C2/C3 dan EKH, tetapi tidak berpengaruh nyata terhadap PBBH (P>0.05). KE, ET, ME, dan RE tertinggi pada M masing-masing 139.52 MJ/hari, 99.69 $\mathrm{MJ} /$ hari, 65.84 MJ/hari, dan 98.45 MJ/hari, rasio RE terhadap KE tertinggi pada B, sedangkan untuk rasio RE terhadap ET, rasio C2/C3, EKH dan PBBH terbaik pada SO yaitu masing-masing 99.24\%, 28.85, 74.97\%, dan $1.24 \mathrm{~kg}$. Penelitian dapat disimpulkan bahwa SO memiliki kemampuan terbaik dalam performans dan memanfaatkan energi pakan.
\end{abstract}

Kata Kunci: Efisiensi energi, Bangsa sapi lokal, Metabolisme energi, Jerami padi

\section{ABSTRACT}

Utami ETW, Bata M, Rahayu S. 2021. Energy metabolism and performance of several local cattle breeds fed rice straw and concentrate. JITV 26(2): 57-64. DOI: http://dx.doi.org/10.14334/jitv.v26i2.2711.

This study was conducted to examine the effect of different local cattle breeds on energy metabolism and performance fed on rice straw basal diet. Fourty local male cattle (2.5 years; initial BW 300.30 \pm 0.68 ) of Madura cattle (M), Sumba Ongole cattle (SO), Bali cattle (B), and Bali Timor cattle (BT) were used in this study, where types of local breed were used as treatments (10 animals/treatment). The study used a randomized block design (RBD) with cattle's initial body weight as a group. The cattle were fed on rice straw ad libitum and concentrate 2.5\% BW (DM 86.53\%). The variables measured were energy intake (EI), digestible energy intake (DEI), metaboloizable energy intake (MEI), energy retention (RE), RE to EI ratio, RE to DEI ratio, C2/C3 ratio, the efficiency of hexose conversion to VFA (ECH) and the average daily body weight gain (ADG). The results showed that the different breeds of local cattle had a significant effect $(\mathrm{P}<0.05)$ on EI, DEI, MEI, RE, RE to EI ratio, RE to DEI ratio, C2/C3 ratio, and $\mathrm{ECH}$, but had no significant effect on ADG (P>0.05). M has the highest EI, DEI, MEI, and RE 139.52 MJ/day, 99.69 MJ/day, $65.84 \mathrm{MJ} /$ day, and $98.45 \mathrm{MJ} /$ day, respectively, but the highest RE to EI ratio at B, while for the best RE to DE ratio, $\mathrm{C} 2 / \mathrm{C} 3 \mathrm{ratio}$, $\mathrm{ECH}$, and ADG, at SO were $99.24 \%, 28.85,74.97 \%$, and $1.24 \mathrm{~kg}$, respectively. It can be concluded that the best local cattle in terms of performance and feed energy efficiency are Sumba Ongole cattle.

Key Words: Energy efficiency, Local cattle breeds, Metabolism energy, Rice straw

\section{INTRODUCTION}

Agricultural waste such as rice straw are used as alternative feed for ruminants to overcome limited land for forage cultivation. However, rice straw has a low digestibility only about 40-50\% (Suryani et al. 2015). To meet energy requirement of livestock, it is necessary to supply energy source or concentrate feeds. Increased price of conventional feed ingredients has generate efforts to increase feed efficiency due to feed could contribute about $60-70 \%$ of the total production costs.

Feed efficiency in ruminants is influenced by the presence of microbes in rumen. About $80 \%$ of ruminant energy needs for metabolism are obtained from the fermentation of feed by rumen microbes (Kong et al. 2016). Various studies have been conducted to manipulate rumen microbial environmental conditions, such as changing maintenance patterns, dietary 
properties, or adding certain additives into feeds (Vera et al. 2014; Khan et al. 2016; Bata \& Rahayua 2017; Soltan \& Patra 2020). Although feeds have significant influences on rumen microbial community (Henderson et al. 2015), in adult ruminants, the attempts to manipulate rumen microbes have only able to survive temporarily (Anderson et al. 2016; Malmuthuge \& Guan 2017; Weimer et al. 2017; Huws et al. 2018). Recent studies have informed a relationship between cattle breeds and the rumen microbial community (HernandezSanabria et al. 2013; Sasson et al. 2017). Although this difference is only a small part, it affected the host performances, including its energy utilization efficiency (John Wallace et al. 2019).

Indonesia has various local cattle breeds including Pesisir cattle, Aceh cattle, Jabres cattle, Pasundan cattle, PO cattle, Sumbawa cattle, Sumba Ongole cattle, Bali cattle and Madura cattle, and those locals cattle are known to have high adaptability to low-quality feed (Hendri 2013). This low-quality feed adaptability is a distinct advantage for local cattle breeds to develop. Local cattle used in this study were Madura cattle, Sumba Ongole cattle, Bali cattle, and Bali Timor cattle, where Sumba Ongole and Bali Timor cattle are extensively raised and grazed in the pasture (Manu 2013; Palandi \& Ngundjuawang 2014), while Bali cattle and Madura cattle are maintained intensively and generally rely on agricultural waste as basal feed (Kutsiyah 2016; Besung et al. 2019). Local cattle breeds are known to have different performances. Sumba Ongole cattle have ADG of 0.8-1.5 kg/day, feed efficiency equal to $10-19 \%$, and percentage of carcass equal to 51-56\% (Agung et al. 2015; Bata et al. 2016; Yantika et al. 2016). Bali cattle have ADG of 0.5-1 kg/day (Hau \& Nulik 2017; Budiari et al. 2020) with percentage of carcass equal to 50-54\% (Suryanto et al. 2017; Neno 2018; Priyono \& Priyanto
2018) while Madura cattle have ADG of 0.2-0.6 kg/day (Wisnuwati et al. 2014; Rab et al. 2016) and percentage of carcass equal to $53 \%$ (Umar et al. 2011). It's presumably because local cattle breeds have different abilities in energy utilization. However, that performance was shown under different conditions and feeds. Therefore, the research objective was to examine the effect of local breeds of cattle on energy metabolism and performance in the same environment and feed. The information obtained can be applied to improve feed efficiency to support the fulfillment of national meat needs.

\section{MATERIALS AND METHODS}

\section{Animal and diets}

Fourty local male cattle aged around 2.5 years old were used in this experiment, consisting of: Madura cattle (M), Sumba Ongole cattle (SO), Bali cattle (B), and Bali Timor cattle (BT). Ten of each M, SO, B, and BT were imported directly from Madura, Sumba Island, Bali Island, and Timor Island, respectively. The average initial body weight of cattle used was $300.30 \pm 0.68 \mathrm{~kg}$.

The cattle were grouped into ten group base on body weight. There were ten groups of body weight, namely $255-263$; 264-272; 273-281; 282-290; 291-299; 300308 ; 309-317; 318-326; 327-335; 336-344. Cattle were fed with rice straw and concentrate. Concentrate was composed of $47.60 \%$ cassava pulp, $24.00 \%$ pollard bran, $10,50 \%$ palm kernel meal, $10.00 \%$ rice bran, $7.00 \%$ soy bean meal, $5.70 \%$ coconut meal, $4.00 \%$ molasses, $1.6 \%$ dolomite, $1.0 \%$ salt, $0.60 \%$ Urea, and $0.30 \%$ mineral mix. The nutrient contents of feed is presented in Table 1.

Table 1. Nutrient of feed during experiment

\begin{tabular}{lcc}
\hline \hline \multirow{2}{*}{ Nutrient Content } & \multicolumn{2}{c}{ Feed } \\
\cline { 2 - 3 } & Rice Straw & Concentrate \\
\hline Dry Matter (\%) & 73.07 & 86.53 \\
Ash (\%) & 23.45 & 17.16 \\
Crude Protein (\%) & 4.00 & 13.82 \\
Crude Fiber (\%) & 31.16 & 19.19 \\
Ether Extract (\%) & 1.3 & 3.97 \\
NFE (\%) & 40.09 & 45.86 \\
TDN (\%) & 38.21 & 64.45 \\
NDF (\%) & 71.43 & 42.83 \\
ADF (\%) & 52.95 & 26.61 \\
Gross Energy (MJ/Kg) & 12.79 & 14.78 \\
\hline Res
\end{tabular}

Result analysis of laboratory according to AOAC (2019)

NFE: Nitrogen-free extract; TDN: Total digestible nutrient; NDF: Neutral detergent fiber; ADF: Acid detergent fiber 


\section{Experimental procedure}

The study was conducted for 52 days, consisted of preliminary study for 14 days and measurement period 38 days. Before the preliminary study cattle was dewormed using Dovenix. The rice straw was bought from the rice fields area in Banyumas, Central Java and sun dried. The concentrate was given twice a day at 07.00 WIB and 15.00 WIB with a total daily offered $2.5 \%$ of body weight. Drinking water and rice straw were offered ad libitum. During the study, cattle were weighed 3 times, before preliminary, before measurement period, and the end of the measurement period using digital scale (SABB, Type:A1GB-3, Cap: 2 ton x 0,5 kg).

Data collection samples of feed (consemed and refusal), feces, and urine was carried out for 5 days using total collection method (Cole \& Ronning 1974). Feed were sampled as much as $250 \mathrm{gr}$. The feed refusal was taken before morning feeding, weighed, and recorded. The samples of feed offered and the refusal dried in an oven at $60^{\circ}$ for $48 \mathrm{~h}$. Feces were collected used a known weight container, sprayed every $4 \mathrm{~h}$ using formalin solution to prevent the decomposition process. Feces were collected for $24 \mathrm{~h}$ then weighed, and recorded. The feces were sampled $( \pm 3 \%)$ and dried in an oven at $60^{\circ} \mathrm{C}$ for $48 \mathrm{~h}$. Feces and feed that had been collected for $5 \mathrm{~d}$ were compiled per individual and subsampled for analysis.

The collection of urine production by seting a diaper/harness made of used tires attached to the part of the cattle's penis that circles its stomach. A plastic hose connected to the bottom of the harness with a jerry can (20 1 capacity), $20 \mathrm{ml}$ of $\mathrm{H}_{2} \mathrm{SO}_{4} 75 \%$ was filled into the can before the urine collection to keep the $\mathrm{pH}$ below 3 to prevent evaporation of ammonia. The urine was collected for $24 \mathrm{~h}$, then the volume was measured, and sample was taken for $20 \mathrm{ml}$. Urine samples were stored in a freezer $\left(-20^{\circ} \mathrm{C}\right)$ until the sample collection was completed. Total urine collected for $5 \mathrm{~d}$ were mixed and stirred until homogen, and then sub samples were taken for analysis.

Rumen fluid samples were taken $3 \mathrm{~h}$ after the morning feeding. Sampling was conducted using a rumenocentesis technique (Petrovski. 2017), sterile needle was injected in the rumen position (done by an expert). The samples were taken as much as $3 \mathrm{ml}$, deposited, and $1.5 \mathrm{ml}$ was separated from the feed sediment. The liquid was then put into the Eppendorf tube and centrifuged at $5000 \mathrm{rpm}$ for 10 minutes. The supernatant was moved into a new tube and stored in a freezer at $-20^{\circ} \mathrm{C}$ until analysis.

At the end of the experiment the cattles were weighed using digital cattle scale and the average daily gain (ADG) was determined by the difference between the final weight and initial weight over the length experiment period. The energy utilization was determined by measuring energy intake (EI), digestible energy intake (DEI), metaboloizable energy intake (MEI), energy retention (RE), RE to EI ratio, and RE to DEI ratio using the total collection method (Cole \& Ronning 1974). RE was determined from the difference between digestible energy intake and the total urin energy output. MEI was determined by the difference between energy retention and methane energy output. Methane energy output was calculated using estimation by Ryle \& Ørskov (1990), ie. (((2pa+2pb)-pp)/4) x 210.8 , pa is the proportion of asetate, $\mathrm{pb}$ is the proportion of butyrate, and $\mathrm{pp}$ is the proportion of propionate. Concentrations of VFA partial was measured using gas chromatography techniques (Guan et al., 2008). The efficiency of conversion of hexose to VFA (ECH) was calculated using estimates by Ryle \& Ørskov (1990), ie. percentage of $(0.622 \mathrm{pa}+1.092 \mathrm{pp}+1.560$ $\mathrm{pb}) /(\mathrm{pa}+\mathrm{pp}+2 \mathrm{pb})$, where $\mathrm{pa}$ is proportion of asetate, $\mathrm{pb}$ is proportion of butyrate, and $\mathrm{pp}$ is proportion of propionate.

\section{Chemical analysis}

Proximate analysis of feed and analysis of moisture content in samples of feces and refusal feed during collection using the procedure AOAC., (2019). Feed, feces, and urine samples were analyzed using a bomb calorimeter (Dittmann et al. 2014) for gross energy and VFA partial from rumen fluids was analyzed using gas chromatography techniques was following procedures described by Guan et al., (2008).

\section{Statistical analysis}

Randomized block design (RBD) (Steel \& Torrie 1993) was applied in this study. The treatments were local cattle breeds, namely M, SO, B, and BT with the initial body weight of cattle as a group. Data were analyzed using analysis of variance and further testing using Duncan's Multiple range tests (DMRT) at level 5\% performed by IBM SPSS statistic 25.0.

\section{RESULTS AND DISCUSSION}

Average Feed Intake, EI, DEI, MEI, RE, RE to EI ratio, RE to DEI ratio, daily fecal energy output, daily urine energy output, methane energy output and the ratio of consumption rice straw and concentrates are presented in Table 2. The variance analysis showed that cattle breeds significantly affected $(\mathrm{P}<0.05) \mathrm{EI}, \mathrm{DEI}, \mathrm{MEI}, \mathrm{RE}$, $\mathrm{RE}$ to EI ratio, RE to DEI ratio. 
The EI of B and SO cattle similar, but was significantly lower than $\mathrm{M}$ and higher than BT. M cattle reasonable ability to consume feed was thought to be more adaptable to the environment's conditions and the feed given. The maintenance pattern on the cattle's origin area affects the cattle's ability to consume the feed. Several studies had revealed that Madura Island and Bali Island is an island with a relatively high density of livestock population so that another alternative to meet requirement for livestock feed, agricultural waste was as feed ingredients and maintain intensively (Kutsiyah 2012; Nugraha et al. 2015; Kutsiyah 2016; Besung et al. 2019). Liu et al., (2016) study using cannula dairy cows revealed that type of forage affects the dynamics of the microbial composition of rumen, where the presence of Fibrobacteria, unclassified Bacteroidales, unclassified Rikenellaceae and unclassified Ruminococcaceae digested more of low-quality forage such as rice straw than alfalfa hay. The ratio consumption of concentrate and rice straw (Table 2), show that $\mathrm{M}$ and $\mathrm{B}$ were able to consume more rice straw compared to SO and BT.
The lower rice straw consumption in SO and BT due to SO and BT originated from Sumba island and Timor island in which they were raised extensively with source of forage from pasture land, beside that various types of legumes have been planted to improve quality of the pasture (Palandi \& Ngundjuawang 2014; Kleden et al. 2015; Hau \& Nulik 2017), because SO and BT initially consumes better quality forage, possibly the fewer microbes able to digested low-quality feed. Zhang et al., (2014) mention that forages with more complex nutrients require greater microbial complexity to utilize all the components of the forage efficiently.

In contrast to EI, DEI and MEI showed differences significantly $(\mathrm{P}<0.05)$ for each local breed. This is due to the difference in energy wasted through feces, urine, and methane. M had the highest DEI and MEI, namely 99.69 $\mathrm{MJ} / \mathrm{d}$ and $65.84 \mathrm{MJ} / \mathrm{d}$, respectively, while the lowest was in BT at $79.51 \mathrm{MJ} / \mathrm{d}$ and $46.91 \mathrm{MJ} / \mathrm{d}$. The low DEI and MEI in BT were due to BT consuming less energy, besides that, the energy lost through excreta and urine on

Table 2. Metabolism of energy on several breeds of local cattle

\begin{tabular}{|c|c|c|c|c|}
\hline \multirow{2}{*}{ Parameter } & \multicolumn{4}{|c|}{ Cattle Breeds } \\
\hline & M & SO & B & BT \\
\hline Feed Intake (DM/kg) & $9.92 \pm 0.01^{\mathrm{c}}$ & $8.79 \pm 0.02^{b}$ & $9.00 \pm 0.06^{\mathrm{b}}$ & $7.84 \pm 0.03^{\mathrm{a}}$ \\
\hline Concentrate (DM/kg) & $6.34 \pm 0.03^{b}$ & $6.32 \pm 0.02^{\mathrm{b}}$ & $5.57 \pm 0.04^{\mathrm{a}}$ & $5.60 \pm 0.02^{\mathrm{a}}$ \\
\hline Rice Straw (DM/kg) & $3.58 \pm 0.03^{\mathrm{c}}$ & $2.46 \pm 0.03^{\mathrm{b}}$ & $3.43 \pm 0.02^{c}$ & $2.24 \pm 0.03^{\mathrm{a}}$ \\
\hline $\mathrm{C} / \mathrm{RS}$ ratio $(\%)$ & $64: 36$ & $72: 28$ & $62: 38$ & $71: 29$ \\
\hline Energy Intake (MJ/d) & $139.52 \pm 0.17^{\mathrm{c}}$ & $124.95 \pm 0.30^{\mathrm{b}}$ & $126.25 \pm 0.87^{\mathrm{b}}$ & $111.44 \pm 0.47^{\mathrm{a}}$ \\
\hline Energy Intake $\left(\mathrm{kJ} / \mathrm{kg} \mathrm{BW} \mathrm{W}^{0.75}\right)$ & $1836.35 \pm 2.27^{\mathrm{c}}$ & $1703.05 \pm 4.11^{\mathrm{b}}$ & $1557.53 \pm 10.73^{\mathrm{a}}$ & $1531.32 .31 \pm 6.46^{\mathrm{a}}$ \\
\hline Fecal Energy (MJ/kg) & $11.78 \pm 0.04$ & $11.65 \pm 0.06$ & $11.76 \pm 0.04$ & $12.56 \pm 0.06$ \\
\hline Fecal Energy Output (MJ/d) & $39.83 \pm 0.15^{\mathrm{c}}$ & $38.62 \pm 0.25^{\mathrm{b}}$ & $32.53 \pm 0.15^{\mathrm{a}}$ & $31.93 \pm 0.19^{\mathrm{a}}$ \\
\hline Fecal Energy Output $\left(\mathrm{kJ} / \mathrm{kg} \mathrm{BW}^{0.75}\right)$ & $524 . .23 \pm 2.03^{c}$ & $526.45 \pm 3.35^{\mathrm{c}}$ & $401.27 \pm 1.89^{\mathrm{a}}$ & $438.81 \pm 2.62^{\mathrm{b}}$ \\
\hline Digested Energy Intake (MJ/d) & $99.69 \pm 0.20^{\mathrm{d}}$ & $86.33 \pm 0.34^{\mathrm{b}}$ & $93.72 \pm 0.77^{\mathrm{c}}$ & $79.51 \pm 0.29^{\mathrm{a}}$ \\
\hline Digested Energy Intake $\left(\mathrm{kJ} / \mathrm{kg} \mathrm{BW} \mathrm{BW}^{0.75}\right)$ & $1312.12 \pm 2.59^{\mathrm{c}}$ & $1176.61 \pm 4.62^{\mathrm{b}}$ & $1156.26 \pm 9.51^{\mathrm{b}}$ & $1092.77 \pm 3.96^{\mathrm{a}}$ \\
\hline Energy Digestibility (\%) & $71.45 \pm 0.11^{\mathrm{b}}$ & $69.09 \pm 0.19^{\mathrm{a}}$ & $74.22 \pm 0.13^{\mathrm{c}}$ & $71.35 \pm 0.06^{\mathrm{b}}$ \\
\hline Urine Energy (kkal/g) & $0.04 \pm 0.001$ & $0.02 \pm 0.001$ & $0.04 \pm 0.001$ & $0.04 \pm 0.002$ \\
\hline Urine Energy Output (MJ/d) & $1.24 \pm 0.02^{\mathrm{b}}$ & $0.66 \pm 0.02^{\mathrm{a}}$ & $1.18 \pm 0.02^{\mathrm{b}}$ & $1.18 \pm 0.05^{\mathrm{b}}$ \\
\hline Urine Energy Output $\left(\mathrm{kJ} / \mathrm{kg} \mathrm{BW}^{0.75}\right)$ & $16.36 \pm 0.26^{\mathrm{b}}$ & $8.97 \pm 0.25^{\mathrm{a}}$ & $14.50 \pm 0.22^{\mathrm{b}}$ & $16.18 \pm 0.64^{\mathrm{b}}$ \\
\hline Methane Energy Output (MJ/d) & $32.61 \pm 0.22^{\mathrm{b}}$ & $28.77 \pm 0.29^{\mathrm{a}}$ & $30.76 \pm 0.41^{\mathrm{ab}}$ & $31.42 \pm 0.32^{\mathrm{b}}$ \\
\hline Methane Energy Output $\left(\mathrm{kJ} / \mathrm{kg} \mathrm{BW}{ }^{0.75}\right)$ & $429.21 \pm 2.92^{\mathrm{b}}$ & $392.15 \pm 3.91^{\mathrm{a}}$ & $379.45 \pm 5.09^{\mathrm{a}}$ & $431.83 \pm 4.34^{\mathrm{b}}$ \\
\hline Metaboloizable Energy Intake (MJ/d) & $65.84 \pm 0.29^{\mathrm{d}}$ & $59.90 \pm 0.44^{\mathrm{b}}$ & $61.79 \pm 0.36^{\mathrm{c}}$ & $46.91 \pm 0.12^{\mathrm{a}}$ \\
\hline Metaboloizable Energy Intake $\left(\mathrm{kJ} / \mathrm{kg} \mathrm{BW} \mathrm{BW}^{0.75}\right)$ & $866.55 \pm 3.86^{\mathrm{c}}$ & $775.49 \pm 5.96^{\mathrm{b}}$ & $762.31 \pm 4.41^{\mathrm{b}}$ & $644.77 \pm 159^{a}$ \\
\hline Energy Retention (MJ/d) & $98.45 \pm 0.21^{\mathrm{d}}$ & $85.67 \pm 0.34^{\mathrm{b}}$ & $92.55 \pm 0.76^{\mathrm{c}}$ & $78.33 \pm 0.29^{\mathrm{a}}$ \\
\hline Energy Retention $\left(\mathrm{kJ} / \mathrm{kg} \mathrm{BW} \mathrm{BW}^{0.75}\right)$ & $1295.76 \pm 2.74^{\mathrm{c}}$ & $1167.64 \pm 4.53^{\mathrm{b}}$ & $1141.76 \pm 9.44^{\mathrm{b}}$ & $1076.60 \pm 3.97^{\mathrm{a}}$ \\
\hline RE to EI Ratio (\%) & $70.56 \pm 0.11^{\mathrm{b}}$ & $68.56 \pm 0.19^{\mathrm{a}}$ & $73.29 \pm 0.13^{\mathrm{c}}$ & $70.30 \pm 0.09^{\mathrm{b}}$ \\
\hline RE to DEI Ratio (\%) & $98.75 \pm 0.02^{\mathrm{a}}$ & $99.24 \pm 0.02^{\mathrm{b}}$ & $98.74 \pm 0.02^{\mathrm{a}}$ & $98.52 \pm 0.06^{\mathrm{a}}$ \\
\hline
\end{tabular}

M: Madura cattle; SO: Sumba Ongole cattle; B: Bali cattle; BT: Bali Timor cattle; C/RS ratio: Ratio of concentrate and rice straw intake a,b,c,d The difference superscripts in the same line show a significant effect $(\mathrm{P}<0.05)$ 
Table 3. VFA production and efficiency of the conversion of hexose to VFA(ECH) of various breeds of local cattle

\begin{tabular}{lcccc}
\hline \hline \multirow{2}{*}{ Parameter } & \multicolumn{3}{c}{ Cattle breeds } \\
\cline { 2 - 5 } & $\mathrm{M}$ & $\mathrm{SO}$ & $\mathrm{B}$ & $\mathrm{BT}$ \\
\hline Acetic acid (mMol) & $68.83 \pm 4.64$ & $73.67 \pm 3.49$ & $56.24 \pm 4.51$ & $55.74 \pm 1.59$ \\
Propionic acid (mMol) & $16.58 \pm 1.06^{\mathrm{a}}$ & $25.86 \pm 1.21^{\mathrm{b}}$ & $16.28 \pm 1.63^{\mathrm{a}}$ & $15.27 \pm 0.73^{\mathrm{a}}$ \\
Butyric acid (mMol) & $9.61 \pm 0.67$ & $10.66 \pm 0.48$ & $8.14 \pm 0.70$ & $7.77 \pm 0.27$ \\
C2/C3 ratio & $4.15 \pm 0.10^{\mathrm{b}}$ & $2.85 \pm 0.07^{\mathrm{a}}$ & $3.45 \pm 0.14^{\mathrm{b}}$ & $3.65 \pm 0.11^{\mathrm{b}}$ \\
ECH (\%) & $72.50 \pm 0.14^{\mathrm{a}}$ & $74.97 \pm 0.18^{\mathrm{b}}$ & $73.69 \pm 0.27^{\mathrm{ab}}$ & $73.26 \pm 0.20^{\mathrm{ab}}$ \\
Initial body weight (kg) & $302.60 \pm 1.79$ & $327.40 \pm 2.58$ & $289.10 \pm 1.69$ & $282.10 \pm 2.47$ \\
Final body weight (kg) & $340.56 \pm 2.33$ & $374.65 \pm 2.98$ & $325.35 \pm 1.54$ & $317.71 \pm 2.43$ \\
ADG (kg) & $0.98 \pm 0.02$ & $1.24 \pm 0.02$ & $0.95 \pm 0.02$ & $0.72 \pm 0.12$ \\
\hline
\end{tabular}

M: Madura cattle; SO: Sumba Ongole cattle; B: Bali cattle; BT: Bali Timor cattle

a,b,c,d The difference superscripts in the same line show a significant effect $(\mathrm{P}<0.05)$

B was also not small. This is consistent with Van Zijderveld et al., (2011) that if the DE intake is not used much for methane formation, it will increase the ME intake.

Energy retention was affected by cattle breed $(\mathrm{P}<0.05)$. According to Amtiran et al. (2016), increased feed intake with high digestibility will increase energy retention in the body, where at the percentage of rice straw $80 \%, 70 \%$, and $60 \%$, energy consumption and energy retention in female local goat are $1661.11 \mathrm{kkal} /$ day $(1379.91 \mathrm{kkal} / \mathrm{d}), 1689.54 \mathrm{kkal} / \mathrm{day}$ (1397.02 kkal/day), and $1720.08 \mathrm{kkal} /$ day (1437.59 $\mathrm{kkal} /$ day), respectively. The results of this study show the same thing (Table 2), $\mathrm{M}$ consume higher feed, so that $\mathrm{M}$ had the highest RE, and the lowest was BT. RE to EI ratio was lowest at SO $(68.56 \%)$, which was significantly different $(\mathrm{P}<0.05)$ from the other three breeds of cattle, but at $\mathrm{M}(70.56 \%)$ and BT $(70.30 \%)$, there was a similar value $(\mathrm{P}>0.05)$. Different results were that $\mathrm{SO}$ actually had a higher RE to DEI ratio, which was $99.24 \%$ $(\mathrm{P}<0.05)$, while the other three breeds of cattle did not show any differences $(\mathrm{P}>0.05)$. This is because the energy lost through excreta on SO is less so that more energy can be used by cattle for maintenance and producing meat.

Consumption of higher concentrates in SO and BT should lead to lower methane gas formation than $\mathrm{M}$ and B. The low production of methane gas $\left(\mathrm{CH}_{4}\right)$ is due to the availability of hydrogen $\left(\mathrm{H}_{2}\right)$ in the rumen, which is more used for the synthesis of propionic acid $\left(\mathrm{C}_{3}\right)$ (Beauchemin et al. 2020). However, Table 2 shows different results. Only SO produces lower methane gas, while BT produces more methane gas compared to B and almost equal to $\mathrm{M}$. This reinforces the statement that the amount of methane gas formed is not only from feed given (Zhou et al. 2011), but other factors have important contribution to the formation of methane gas (Basarab et al. 2013). Several studies have revealed that large amount of methane gas emissions apart from feed is also affected by cattle genetics (Pinares-Patiño et al. 2013; Tapio et al. 2017; Auffret et al. 2018). Roehe et al. (2016) revealed that there is differences in microbial communities with low methane emissions and high methane emissions, where methane gas emissions in sire progeny Aberdeen Angus cattle were smaller than that of limousine cattle. This difference in microbial communities is thought to be due to the presence of core microbes that are genetically inherited and responsible for the formation of methane gas (Wallace et al. 2015; John Wallace et al. 2019; Li, Hitch, et al. 2019; Li, Li, et al. 2019; Abbas et al. 2020).

Methane gas formation is influenced by production of VFA, and it affects the ECH value (Beauchemin et al. 2020). The average concentration of acetic acid, propionic, butyric acid, $\mathrm{C} 2 / \mathrm{C} 3$ ratio, $\mathrm{ECH}$, and $\mathrm{ADG}$ are presented in Table 3. Differences in local cattle breeds did not affect (P> 0.5) acetate and butyrate concentrations but did affect $(\mathrm{P}<0.05)$ propionate concentration, $\mathrm{C} 2 / \mathrm{C} 3$ ratio, and $\mathrm{ECH}$. The propionate concentration of $\mathrm{M}$ cattle was similar to $\mathrm{B}$ and $\mathrm{BT}(\mathrm{P}>$ $0.05)$ but lower than $\mathrm{SO}(\mathrm{P}<0.05)$. It causes the $\mathrm{C} 2 / \mathrm{C} 3$ ratio of SO was the lowest than the other three breeds of cattle. The ratio of $\mathrm{C} 2 / \mathrm{C} 3$ in $\mathrm{SO}$ was also better than Cherdthong et al., (2014), with the same basal feed, namely rice straw, Thai native beef cattle had a $\mathrm{C} 2 / \mathrm{C} 3$ ratio of 3.8 , because, in that research, the consumption of rice straw was higher than concentrate. The $\mathrm{C} 2 / \mathrm{C} 3$ ratio shows the amount of rumen microbes that can form acetic (acetogenic) or propionic acid (glucogenic), and it can be used to measure the efficiency of energy use in ruminants (Syapura et al. 2013). That was consistent with Muktiani et al., (2020) statement that a low C2/C3 ratio also indicates a higher ECH. Table 3. also shows that the $\mathrm{ECH}$ in SO is higher than the three other local cattle breeds. ECH on SO higher than $\mathrm{M}$ but was not significantly different to B and BT. According to Sari et 
al. (2019), the high amount of fermentable organic matter causes a low $\mathrm{C} 2 / \mathrm{C} 3$ ratio, this is because of Propionibacteria sp, Veillonella alkalescens, dan Peptostreptococcus elsdenii will use more lactic acid for the formation of propionic acid, which is a precursor for gluconeogenesis. Increased propionic acid concentration causes an increase in glucose production in the blood (Klau Tahuk et al. 2017). Ladeira et al. (2018) explained that meat production and the quality of marbling formation were influenced by glucose availability in the blood. Although local cattle breeds did not significantly affect $\mathrm{ADG}(\mathrm{P}>0.05)$, but $\mathrm{ADG}$ on $\mathrm{SO}$ was higher than the three other breeds $(P=0.12)$, namely $1.24 \mathrm{~kg}$. The ADG of SO recorded by Yantika et al., (2016) could reach $1-1.57 \mathrm{~kg}$.

\section{CONCLUSION}

Madura, Sumba Ongole, Bali, and Bali Timor cattles' abilities to metabolize feed energy were varied. Sumba Ongole cattle was better than the other three local breed cattle in producing higher ADG even though the differences were not significant, so the best local cattle in terms of performance and feed energy efficiency is Sumba Ongole cattle.

\section{REFERENCES}

Abbas W, Howard JT, Paz HA, Hales KE, Wells JE, Kuehn LA, Erickson GE, Spangler ML, Fernando SC. 2020. Influence of host genetics in shaping the rumen bacterial community in beef cattle. Sci Rep. 10: 15101. DOI: 10.1038/s41598-020-72011-9.

Agung PP, Anwar S, Wulandari AS, Sudiro A, Said S, Tappa B. 2015. The potency of sumba Ongole (so) cattle: A study of genetic characterization and carcass productivity. J Indones Trop Anim Agric. 40:71-78. DOI: $10.14710 /$ jitaa.40.2.71-78.

Amtiran I, Nikolaus TT, Abdulah MS. 2016. Pemberian pakan komplit dengan rasio jerami padi dan konsentrat yang berbeda terhadap retensi nitrogen dan energi Kambing Kacang Betina. J Nukl Peternak. 3:136-142. DOI: 10.35508/nukleus.v3i2.799.

Anderson CL, Schneider CJ, Erickson GE, Macdonald JC, Fernando SC. 2016. Rumen bacterial communities can be acclimated faster to high concentrate diets than currently implemented feedlot programs. J Appl Microbiol. 120:588-599. DOI: 10.1111/jam.13039.

AOAC. 2019. Official methods of analysis. 21st editi. USA: AOAC International.

Auffret MD, Stewart R, Dewhurst RJ, Duthie CA, Rooke JA, Wallace RJ, Freeman TC, Snelling TJ, Watson M, Roehe R. 2018. Identification, comparison, and validation of robust rumen microbial biomarkers for methane emissions using diverse Bos taurus breeds and basal diets. Front Microbiol. 8:1-15. DOI: 10.3389/fmicb.2017.02642.

Basarab JA, Beauchemin KA, Baron VS, Ominski KH, Guan LL, Miller SP, Crowley JJ. 2013. Reducing GHG emissions through genetic improvement for feed efficiency: effects on economically important traits and enteric methane production. Animal. 7:303-315. DOI: $10.1017 / \mathrm{S} 1751731113000888$.

Bata M, Rahayu S. 2017. Evaluation of bioactive substances in Hibiscus tiliaceus and its potential as a ruminant feed additive. Curr Bioact Compd. 13:157-164. DOI: 10.2174/1573407213666170109151904.

Bata M, Rahayu S, Hidayat N. 2016. Performan Sapi Sumba Ongole (SO) yang diberi jerami padi amoniasi dan konsentrat yang disuplementasi dengan tepung daun Waru (Hibiscus tiliaceus). J Agripet. 16:106-113.

Beauchemin KA, Ungerfeld EM, Eckard RJ, Wang M. 2020. Review: Fifty years of research on rumen methanogenesis: Lessons learned and future challenges for mitigation. Animal. 14:s2-s16. DOI: 1017/S1751731119003100.

Besung INK, Watiniasih NL, Kade Mahardika GN, Karang Agustina K, Suwiti NK. 2019. Mineral levels of bali cattle (Bos javanicus) from different types of land in bali, Nusa Penida, and Sumbawa Islands (Indonesia). Biodiversitas. 20:2931-2936. DOI: 10.13057/biodiv/d201022.

Budiari NLG, Kertawirawan IPA, Adijaya IN, Yasa IMR. 2020. Pengaruh pemberian konsentrat terhadap pertumbuhan dan kecernaan pakan pada penggemukan Sapi Bali. J Pengkaj dan Pengemb Teknol Pertan. 23:8190. DOI: 10.21082/jpptp.v23n1.2020.p83-92.

Cherdthong A, Wanapat M, Wongwungchun W, Yeekeng S, Niltho T, Rakwongrit D, Khota W, Khantharin S, Tangmutthapattharakun G, Phesatcha K, et al. 2014. Effect of feeding feed blocks containing different levels of urea calcium sulphate mixture on feed intake, digestibility and rumen fermentation in Thai native beef cattle fed on rice straw. Anim Feed Sci Technol. 198:151-157. DOI: 10.1016/j.anifeedsci.2014.10.016.

Cole HH, Ronning M. 1974. Animal Agriculture: The Biology of Domestic Animal and their Use by Man. 1st Editio. San Francisco (US): W. H. Freeman and Company.

Dittmann MT, Hebel C, Hammer S, Hummel J, Ortmann S, Arif A, Bouts T, Kreuzer M, Clauss M. 2014. Energy requirements and metabolism of the Phillip's dikdik (Madoqua saltiana phillipsi). Comp Biochem Physiol A Mol Integr Physiol. 167:45-51. DOI: 10.1016/j.cbpa.2013.09.014.

Guan LL, Nkrumah JD, Basarab JA, Moore SS. 2008. Linkage of microbial ecology to phenotype: Correlation of rumen microbial ecology to cattle's feed efficiency. FEMS Microbiol Lett. 288:85-91.

Hau DK, Nulik J. 2017. Kajian pengembangan dan pemanfaatan tanaman pakan leguminosa mendukung peningkatan produksi ternak sapi di Nusa Tenggara Timur. In: Pros Semin Nas Teknol Peternak dan Vet 
2017. Bogor: IAARD Press; p. 585-594. DOI: 10.14334/Pros.Semnas.TPV-2017-p.585-594.

Henderson G, Cox F, Ganesh S, Jonker A, Young W, Janssen PH, Abecia L, Angarita E, Aravena P, Arenas GN, et al. 2015. Rumen microbial community composition varies with diet and host, but a core microbiome is found across a wide geographical range. Sci Rep. 5:1-15. DOI: 10.1038/srep14567.

Hendri Y. 2013. Dinamika Pengembangan Sapi Pesisir sebagai Sapi Lokal Sumatera Barat. J litbang Pertan. 32:39-46.

Hernandez-Sanabria E, Goonewardene LA, Wang Z, Zhou M, Moore SS, Guan LL. 2013. Influence of sire breed on the interplay among rumen microbial populations inhabiting the rumen liquid of the Progeny in Beef Cattle. PLoS One. 8:1-15. DOI: 10.1371/journal.pone.0058461.

Huws SA, Creevey CJ, Oyama LB, Mizrahi I, Denman SE, Popova M, Muñoz-Tamayo R, Forano E, Waters SM, Hess M, et al. 2018. Addressing global ruminant agricultural challenges through understanding the rumen microbiome: Past, present, and future. Front Microbiol. 9:1-33. DOI: 10.3389/fmicb.2018.02161.

John Wallace R, Sasson G, Garnsworthy PC, Tapio I, Gregson E, Bani P, Huhtanen P, Bayat AR, Strozzi F, Biscarini F, et al. 2019. A heritable subset of the core rumen microbiome dictates dairy cow productivity and emissions. Sci Adv. 5:1-12. DOI: 10.1126/sciadv.aav8391.

Khan RU, Naz S, Dhama K, Karthik K, Tiwari R, Abdelrahman MM, Alhidary IA, Zahoor A. 2016. Direct-fed microbial: Beneficial applications, modes of action and prospects as a safe tool for enhancing ruminant production and safeguarding health. Int J Pharmacol. 12:220-231. DOI: 10.3923/ijp.2016.220.231.

Klau Tahuk P, Agung Dethan AAD, Sio S. 2017. Profil glukosa dan urea darah sapi Bali jantan pada penggemukan dengan hijauan (Greenlot Fattening) di Peternakan Rakyat. J Agripet. 17:104-111.

Kleden MM, Ratu MR., Randu MD. 2015. Kapasitas tampung hijauan pakan dalam areal perkebunan kopi dan padang rumput alam di Kabupaten Flores Timur Nusa Tenggara Timur. ZOOTEC. 35:340-350. DOI: 10.35792/zot.35.2.2015.9274.

Kong RSG, Liang G, Chen Y, Stothard P, Guan LL. 2016. Transcriptome profiling of the rumen epithelium of beef cattle differing in residual feed intake. BMC Genomics. 17:1-16. DOI: 10.1186/s12864-016-2935-4.

Kutsiyah F. 2012. Analisis pembibitan sapi potong di pulau Madura. Wartazoa. 22:113-126.

Kutsiyah F. 2016. Pengembangan agribisnis sapi bibit Madura melalui pendekatan One Tambon One Product (OTOP) di Pulau Madura. Maduranch. 1:29-40.

Ladeira MM, Schoonmaker JP, Swanson KC, Duckett SK, Gionbelli MP, Rodrigues LM, Teixeira PD. 2018. Review: Nutrigenomics of marbling and fatty acid profile in ruminant meat. Animal. 12:268-294. DOI: Review: Nutrigenomics of marbling and fatty acid profile in ruminant meat. DOI: 10.1017/S1751731118001933.
Li F, Hitch TCA, Chen Y, Creevey CJ, Guan LL. 2019. Comparative metagenomic and metatranscriptomic analyses reveal the breed effect on the rumen microbiome and its associations with feed efficiency in beef cattle. Microbiome. 7:1-21. DOI: 10.1186/s40168-019-0618-5.

Li F, Li C, Chen Y, Liu J, Zhang C, Irving B, Fitzsimmons C, Plastow G, Guan LL. 2019. Host genetics influence the rumen microbiota and heritable rumen microbial features associate with feed efficiency in cattle. Microbiome. 7:117. DOI: 10.1186/s40168-019-0699-1.

Liu J, Zhang M, Xue C, Zhu W, Mao S. 2016. Characterization and comparison of the temporal dynamics of ruminal bacterial microbiota colonizing rice straw and alfalfa hay within ruminants. J Dairy Sci. 99:9668-9681. DOI: 10.3168/jds.2016-11398

Malmuthuge N, Guan LL. 2017. Understanding host-microbial interactions in rumen: Searching the best opportunity for microbiota manipulation. J Anim Sci Biotechnol. 8:1-7. DOI: 10.1186/s40104-016-0135-3.

Manu A. 2013. Produktivitas Padang Penggembalaan Sabana Timor Barat. Pastura J Trop Forage Sci. 3:25-29. DOI: 10.24843/Pastura.2013.v03.i01.p07.

Muktiani A, Arifah N, Widiyanto W. 2020. Influence of different vegetable oils on in vitro ruminal fermentability and nutrient digestibility in Ettawah Crossbred Goat. Anim Prod. 21:22-29.

Neno M. 2018. Korelasi bobot potong terhadap produksi karkas ternak Sapi Bali di RPH Kota Kefamenanu. J Anim Sci. 3:60-62. DOI: 10.32938/ja.v3i4.545.

Nugraha C, Maylinda S, Nasich M. 2015. Karakteristik Sapi Sonok dan Sapi Karapan pada umur yang berbeda di Kabupaten Pamekasan Pulau Madura. J Trop Anim Prod. 16:55-60. DOI: 10.21776/ub.jtapro.2015.016.01.9.

Palandi JF, Ngundjuawang AU. 2014. Analisis dan perancangan sistem informasi geografis lahan dan tata ruang wilayah peternakan di Kabupaten Sumba Timur berbasis Web. Teknol Inf Terap. 1:87-94.

Petrovski KR. 2017. Assessment of the Rumen Fluid of a Bovine Patient. J Dairy Vet Sci. 2:1-7.

Pinares-Patiño CS, Hickey SM, Young EA, Dodds KG, MacLean S, Molano G, Sandoval E, Kjestrup H, Harland R, Hunt C, et al. 2013. Heritability estimates of methane emissions from sheep. Animal. 7:316-321. DOI: $10.1017 / \mathrm{S} 1751731113000864$.

Priyono P, Priyanto D. 2018. Partnership program on Bali cattle fattening based on local resources in the suboptimal land area of Nusa Tenggara Timur. Indones Bull Anim Vet Sci. 28:61-68. DOI: 10.14334/wartazoa.v28i2.1652.

Rab SA, Priyanto R, Fuah AM, Wiryawan IKG. 2016. Daya Dukung dan Eisiensi Produksi Sapi Madura dengan Pemanfaatan Limbah Kacang Kedalai. J Ilmu Produksi dan Teknol Has Peternak. 4(3):340-344.

Roehe R, Dewhurst RJ, Duthie CA, Rooke JA, McKain N, Ross DW, Hyslop JJ, Waterhouse A, Freeman TC, Watson M, Wallace RJ. 2016. Bovine Host Genetic Variation Influences Rumen Microbial Methane Production with 
Best Selection Criterion for Low Methane Emitting and Efficiently Feed Converting Hosts Based on Metagenomic Gene Abundance. PLoS Genet. 12(2):120.

Ryle M, Ørskov ER. 1990. Energy Nutrition in Ruminants. Netherland: Springer.

Sari NF, Ridwan R, Rohmatussolihat, Fidriyanto R, Astuti WD, Widyastuti Y. 2019. The Effect of Probiotics on High Fiber Diet in Rumen Fermentation Characteristics. In: IOP Conf Ser Earth Environ Sci. Tanggerang, Indonesia: IOP Publishing; p. 1-7.

Sasson G, Ben-Shabat SK, Seroussi E, Doron-Faigenboim A, Shterzer N, Yaacoby S, Miller MEB, White BA, Halperin E, Mizrahi I. 2017. Heritable bovine rumen bacteria are phylogenetically related and correlated with the cow's capacity to harvest energy from its feed. MBio. 8(4):112.

Soltan YA, Patra AK. 2020. Bee propolis as a natural feed additive: Bioactive compounds and effects on ruminal fermentation pattern as well as productivity of ruminants. Indian J Anim Heal. 59(2):50-61.

Steel RG., Torrie J. 1993. Prinsip dan Prosedur Statistika Suatu Pendekatan Biometrik. Jakarta: Gramedia.

Suryani NN, Mahardika IG, Putra S, Sujaya N. 2015. Sifat Fisik dan Kecernaan Ransum Sapi Bali yang Mengandung Hijauan Beragam. Indones J Anim Sci. 17(1):38-45.

Suryanto E, Bulkaini B, Soeparno S, Karda IW. 2017. Kualitas Karkas, Marbling, Kolesterol Daging Dan Komponen Non Karkas Sapi Bali Yang Diberi Pakan Kulit Buah Kakao Fermentasi. Bul Peternak. 41(1):72-78.

Syapura S, Bata M, Pratama WS. 2013. Peningkatan Kualitas Jerami Padi dan Pengaruhnya Terhadap Kecernaan Nutrien dan Produk Fermentasi Rumen Kerbau dengan Feces Sebagai Sumber Inokulum. J Agripet. 13(2):5967.

Tapio I, Snelling TJ, Strozzi F, Wallace RJ. 2017. The ruminal microbiome associated with methane emissions from ruminant livestock. J Anim Sci Biotechnol. 8(1):1-11.
Umar M, Arifin M, Purnomoadi A. 2011. Ruminal condition between Madura cattle and Ongole Crossbred cattle raised under intensive feeding. J Indones Trop Anim Agric. 36(3):213-218.

Vera JK, Briceño EG, Ruíz A, Mayo R, Ayala A, Aguilar. CF, Solorio F, Ramirez L. 2014. Manipulación del metabolismo energético de los rumiantes en los trópicos: opciones para mejorar la producción y la calidad de la carne y leche. Rev Cuba Cienc Agrícola. 48(1):43-53.

Wallace RJ, Rooke JA, McKain N, Duthie CA, Hyslop JJ, Ross DW, Waterhouse A, Watson M, Roehe R. 2015. The rumen microbial metagenome associated with high methane production in cattle. BMC Genomics. 16(1):114.

Weimer PJ, Cox MS, Vieira de Paula T, Lin M, Hall MB, Suen G. 2017. Transient changes in milk production efficiency and bacterial community composition resulting from near-total exchange of ruminal contents between highand low-efficiency Holstein cows. J Dairy Sci. 100(9):7165-7182.

Wisnuwati S, Dartosukarno, A Purnomoadi. 2014. Respon Fisiologis Harian Sapi Madura Jantan yang Diberi Pakan dengan Kuantitas Berbeda. Anim Agric J. 3(3):389-394.

Yantika SM, Alamsyari, Evvyernie D, Diapari D, Winaga K. 2016. Performance, carcass production, and meat quality of sumba ongole bulls fed ration supplemented velvet bean (Mucuna pruriens). Media Peternak. 39(1):20-26.

Zhang R, Zhu Weiyun, Zhu Wen, Liu J, Mao S. 2014. Effect of dietary forage sources on rumen microbiota, rumen fermentation and biogenic amines in dairy cows. J Sci Food Agric. 94(9):1886-1895.

Zhou M, Chung YH, Beauchemin KA, Holtshausen L, Oba M, McAllister TA, Guan LL. 2011. Relationship between rumen methanogens and methane production in dairy cows fed diets supplemented with a feed enzyme additive. J Appl Microbiol. 111(5):1148-1158.

Van Zijderveld SM, Gerrits WJJ, Dijkstra J, Newbold JR, Hulshof RBA, Perdok HB. 2011. Persistency of methane mitigation by dietary nitrate supplementation in dairy cows. J Dairy Sci. 94(8):4028-4038. 